\title{
Hepatitis $B$ and $C$ prevalence among heroin addicts in methadone maintenance treatment (MMT) and not in MMT in Pereira, Colombia
}

\author{
Juan C Sepúlveda-Arias ${ }^{1,2}$, Carlos Isaza ${ }^{1,2}$, Juan Pablo Vélez ${ }^{3}$ \\ ${ }^{1}$ Departamento de Ciencias Básicas, Facultad de Ciencias de la Salud, Universidad Tecnológica de Pereira, \\ Pereira, Risaralda, Colombia \\ 2. Programa de Medicina, Fundación Universitaria Autónoma de las Américas, Seccional Pereira, Pereira, \\ Risaralda, Colombia \\ 3.Programa de Mantenimiento con Metadona, Hospital Mental de Risaralda (HOMERIS), Pereira, Risaralda, \\ Colombia
}

Key words: Heroin dependence; methadone; HCV; HBV.

J Infect Dev Ctries 2014; 8(9):1228-1230. doi:10.3855/jidc.4525

(Received 09 December 2013 - Accepted 18 June 2014)

Copyright (C) 2014 Sepúlveda-Arias et al. This is an open-access article distributed under the Creative Commons Attribution License, which permits unrestricted use, distribution, and reproduction in any medium, provided the original work is properly cited.

In a recent systematic review, Nelson et al showed that injection drug abuse is an important factor associated with a high prevalence of hepatitis $C$ virus (HCV) and hepatitis B virus (HBV) infection [1]. In that review, only data from Argentina, Brazil, Mexico, Paraguay and Uruguay were included, due to the lack of information on other countries in Latin America and in the Caribbean.

After an extensive literature search about the prevalence of injection drug use in Colombia, only four reports were found on three different Colombian cities. The prevalence of intravenous heroin administration in Medellin ranges between $0.2 \%$ in a prison population (VESPA Survey reported by Castaño) [2] and 24\% in drug addiction treatment centers [3]. However, a comparison between both studies cannot be carried out due to differences in sample size, methodology and population evaluated. In Bucaramanga, the prevalence of intravenous illegal drug use in three drug rehabilitation centers and one prison was $4.2 \%$ [4]. Finally, a survey carried out on 895 inhabitants from Pereira showed a prevalence of intravenous drug use of $26.9 \%$, including the use of heroin and cocaine [5] (Figure 1).

Hepatitis $\mathrm{C}$ virus (HCV) testing and counseling are important strategies to potentially reduce $\mathrm{HCV}$ transmission in young adult injection drug users [6]. However, in developing countries, the health systems underappreciate the role of injection drug users (IDU) in the transmission of infectious agents such as $\mathrm{HCV}$, hepatitis B virus (HBV) and human immunodeficiency virus (HIV). Moreover, the treatment of $\mathrm{HCV}$ infection in IDU is still low in developing countries due to patient- and system-related barriers.

Although HCV infection is a public health problem around the world and chronic viral hepatitis are the major etiological factors of end-stage liver diseases, in Colombia there are no studies of HCV and HBV prevalence in IDU. The prevalence of HCV in multi-transfused patients is $9 \%$ [7], whereas a more recent study carried out in 697 inhabitants from four different states showed a frequency of anti-HCV markers of $3.55 \%$ [8]. On the other hand, the prevalence of HBV in Colombia ranges between 1.97 and $8.39 \%$ in several regions [8-10].

As part of an ongoing work evaluating the immune status of IDU and a control population in Pereira, Colombia (approved by the Ethics Committee of Universidad Tecnológica de Pereira) a total of 91 individuals were analyzed in order to determine the presence of anti-HCV using RapidSignal HCV Whole Blood/Serum/Plasma Cassette (Orgenics, Yavne, Israel), anti-HBsAg using RapidSignal HBsAg Serum/Plasma Casette (Orgenics, Yavne, Israel) and anti-HIV antibodies using Alere Determine HIV1/2 Test, (Alere, Galway, Ireland). Blood samples were taken from: 42 patients not in methadone maintenance treatment (non-MMT, Group A, mean age $25.5 \pm 7.6$ years), 29 patients under methadone maintenance treatment (MMT, Group B, mean age $23.8 \pm 4.6$ years) 
and 20 healthy individuals without history of drug use (Group C, mean age $26 \pm 10.4$ years). No significant differences in demographic characteristics between groups were determined $(p=0.55)$. All the studied individuals were recruited at the regional psychiatric hospital (Hospital Mental de Risaralda, HOMERIS) between September 2012 and January 2013. Most of the studied individuals were males $(91.3 \%)$ and $8.7 \%$ were females. The mean duration of heroin use was $5.3 \pm 2.9$ years, without a significant difference between Group A and Group B ( $=0.3)$.

Prevalence of HBV and HIV infections in heroin users was low $(1.1 \%)$ whereas the overall $\mathrm{HCV}$ prevalence was $17.4 \%(21.4 \%$ in patients Non-MMT and $24.1 \%$ in patients under MMT). HIV prevalence was $2.2 \%$ and only one patient in the Non-MMT group $(1.1 \%)$ was co-infected with HIV and HCV. All results are shown in Table 1. The high HCV prevalence found in the IDU is in agreement with several reports from other countries regarding the risk of injection behavior for $\mathrm{HCV}$ infection [1,11-13]. This result is not in agreement with a previous report showing the absence of $\mathrm{HCV}$ infection among illegal drug users in Bucaramanga, Colombia [4] and it may be associated with the low prevalence of heroin use in the studied population $(3.9 \%)$. Several reasons explain why IDU are a high-risk group for HCV infection but the most important is the shared use of injecting equipment and solutions. It is important to consider the impact of opiate abuse on the immune system.
Although these preliminary findings should be confirmed by further studies, the National Health Systems in developing countries need to improve $\mathrm{HCV}, \mathrm{HBV}$ and HIV screening strategies in IDU. To our knowledge, this is the first Colombian report on HBV and HCV infection in heroin addicts under methadone maintenance treatment and not.

Figure 1. Map of Colombia showing the prevalence of injection drug use (mainly heroin) based on the few studies that reported its use.

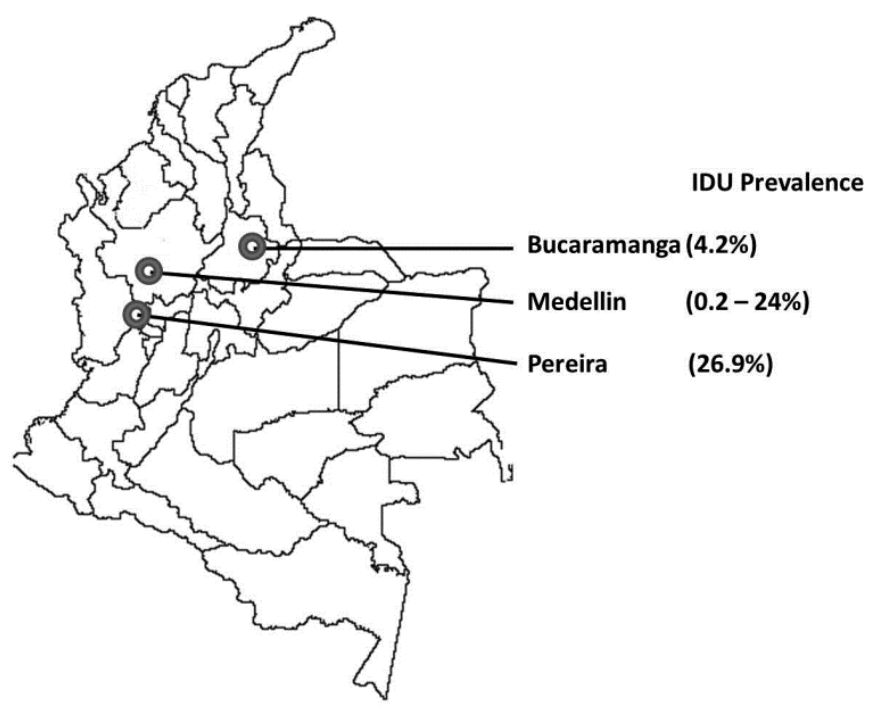

Table 1. Demographic characteristics, HBV, HCV and HIV status of the evaluated population.

\begin{tabular}{|c|c|c|c|}
\hline Variables & $\begin{array}{c}\text { Group A } \\
\text { (Non-MMT) }\end{array}$ & $\begin{array}{l}\text { Group B } \\
\text { (MMT) }\end{array}$ & $\begin{array}{c}\text { Group C } \\
\text { (Healthy Controls) }\end{array}$ \\
\hline Sample Size & 42 & 29 & 20 \\
\hline Age, years $($ mean \pm SD) & $25 \pm 7.6$ & $23.8 \pm 4.6$ & $26.0 \pm 10.4$ \\
\hline \multicolumn{4}{|l|}{ Sex } \\
\hline Male $(\%)$ & $39(92.9)$ & $28(96.6)$ & $16(80.0)$ \\
\hline Female $(\%)$ & $3(7.1)$ & $1(3.4)$ & $4(20.0)$ \\
\hline Positive $(\%)$ & 0 & $1(3.4)$ & 0 \\
\hline Negative $(\%)$ & $42(100)$ & $28(96.6)$ & $20(100)$ \\
\hline \multicolumn{4}{|c|}{ HCV Status (RapidSignal HCV Whole Blood/Serum/Plasma Cassette) } \\
\hline Positive $(\%)$ & $9(21.4)$ & $7(24.1)$ & 0 \\
\hline \multicolumn{4}{|c|}{ HIV status (Alere Determine HIV1/2 Test) } \\
\hline Negative $(\%)$ & $42(100)$ & $28(96.6)$ & $20(100)$ \\
\hline
\end{tabular}

MMT: Methadone Maintenance Treatment; SD: Standard Deviation; HBV: Hepatitis B Virus; HBsAg: Hepatitis B Surface Antigen; HCV: Hepatitis C Virus; HIV: Human Immunodeficiency Virus. 


\section{Acknowledgements}

This work was supported by Vicerrectoría de Investigaciones, Innovación y Extensión, Universidad Tecnológica de Pereira, Colombia (Grant 5-12-6) and Fundación Universitaria Autónoma de las Américas, Seccional Pereira.

\section{References}

1. Nelson PK, Mathers BM, Cowie B, Hagan H, Des Jarlais D, Horyniak D, Degenhardt L (2011) Global epidemiology of hepatitis $\mathrm{B}$ and hepatitis $\mathrm{C}$ in people who inject drugs: results of systematic reviews. Lancet 378: 571-583.

2. Castaño GA (2002) Consumo de heroína en Colombia. Adicciones 14: 87-90.

3. Castaño GA, Calderón GA (2012) Patrones de consumo de heroína en una muestra de consumidores de Medellín Colombia. Rev Bras Epidemiol 15: 504-522.

4. Bautista H, Jaimes BZ, Hincapié ML (2011) Ausencia de infección por virus de la hepatitis $\mathrm{C}$ en usuarios de drogas ilícitas en la ciudad de Bucaramanga, Colombia. Rev Col Gastroenterol 26: 15-20.

5. Observatorio de Drogas Eje Cafetero (2013) Situación del consumo de drogas en el departamento de Risaralda- Sistema único de indicadores sobre consumo de sustancias psicoactivas Available at http://www.odc.gov.co/portals/1/modpublicaciones/pdf/co039 72014-suispa-consumo-drogas-risaralda-abril2014.pdf Accessed on June 10, 2014.

6. Page K, Morris MD, Hahn JA, Maher L, Prins M (2013) Injection drug use and hepatitis $\mathrm{C}$ virus infection in young adult injectors: using evidence to inform comprehensive prevention. Clin infect Dis 57 Suppl 2: 32-38.

7. Beltran M, Navas MC, De la Hoz F, Mercedes Munoz M, Jaramillo S, Estrada C, Del Pilar Cortes L, Arbelaez MP, Donado J, Barco G, Luna M, Uribe GA, de Maldonado A, Restrepo JC, Correa G, Borda P, Rey G, de Neira M, Estrada A, Yepes S, Beltran O, Pacheco J, Villegas I, Boshell J (2005)
Hepatitis C virus seroprevalence in multi-transfused patients in Colombia. J Clin Virol 34 Suppl 2: 33-38.

8. Alvarado-Mora MV, Fernandez MF, Gomes-Gouvea MS, de Azevedo Neto RS, Carrilho FJ, Pinho JR (2011) Hepatitis B (HBV), hepatitis C (HCV) and hepatitis delta (HDV) viruses in the Colombian population--how is the epidemiological situation? PloS one 6: e18888.

9. Ljunggren KE, Patarroyo ME, Engle R, Purcell RH, Gerin JL (1985) Viral hepatitis in Colombia: a study of the "hepatitis of the Sierra Nevada de Santa Marta". Hepatology 5: 299-304.

10. Prieto F, Rojas D (2003) Situación semestral de la hepatitis B, Colombia. Programa ITS/SIDA. Biomédica 8: 2-11.

11. Hagan H, Pouget ER, Williams IT, Garfein RL, Strathdee SA, Hudson SM, Latka MH, Ouellet LJ (2010) Attribution of hepatitis $\mathrm{C}$ virus seroconversion risk in young injection drug users in 5 US cities. J Infect Dis 201: 378-385.

12. Page K, Hahn JA, Evans J, Shiboski S, Lum P, Delwart E, Tobler L, Andrews W, Avanesyan L, Cooper S, Busch MP (2009) Acute hepatitis C virus infection in young adult injection drug users: a prospective study of incident infection, resolution, and reinfection. J Infect Dis 200: 1216-1226.

13. Wang X, Tan L, Li Y, Zhang Y, Zhou D, Liu T, Hao W (2012) HCV and HIV infection among heroin addicts in methadone maintenance treatment (MMT) and not in MMT in Changsha and Wuhan, China. PloS one 7: e45632.

\section{Corresponding author}

Juan C. Sepúlveda-Arias, MD, PhD

Departamento de Ciencias Básicas

Facultad de Ciencias de la Salud

Universidad Tecnológica de Pereira

Pereira - Risaralda

Colombia

Phone: $+57-6-3137127$

Fax: +57-6-3216252

Email: jcsepulv@utp.edu.co

Conflict of interests: No conflict of interests is declared. 